НАУКОВИЙ ВІСНИК

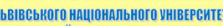

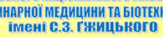
Scientific messenger of Liviv National University
Veterimary Medicine and Bitetechnologies

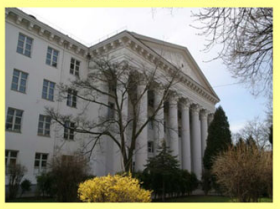

СЕРЯя "ЕКОНОМІчн НАУБМ"

Том 22 № 94 2020
Науковий вісник Аьвівського національного університету ветеринарної медицини та біотехнологій імені С.3. Гжицького. Серія: Економічні науки

\author{
Scientific Messenger of Lviv National University \\ of Veterinary Medicine and Biotechnologies. \\ Series: Economical Sciences
}

\title{
Availability of balanced nutrition at the level of scientific basis for norms of all layers of the population of Ukraine
}

\author{
A. S. Yagodzinskaya \\ Mykolayiv National Agrarian University, Mykolayiv, Ukraine
}

Article info

Received 29.01.2020

Received in revised form 27.02 .2020

Accepted 28.02.2020

Mykolayiv National Agrarian University, Georgy Gongadze Str., 9, Mykolayiv. 54000, Ukraine.

Tel.: +38-067-99-55-154

E-mail: aalbeschenko@gmail.com
Yagodzinskaya, A. S. (2020). Availability of balanced nutrition at the level of scientific basis for norms of all layers of the population of Ukraine. Scientific Messenger of Lviv National University of Veterinary Medicine and Biotechnologies. Series: Economical Sciences, 21(94), 17-21. doi: $10.32718 /$ nvlvet-e 9403

The basis of all life processes of the human body is a constant metabolism between the body and the environment. From the environment, people consume oxygen, water and food. The role of food is to replenish energy and tissue elements necessary for growth, development and functioning of the body, ensuring metabolic processes, normal health and efficiency. Rational nutrition (ratio - reasonable) is a physiologically complete nutrition of healthy people taking into account their age, sex, nature of work and other factors. Nutritional nutrition contributes to maintaining good health, resistance to harmful environmental factors, high physical and mental capacity, as well as active longevity. The article is devoted to the issues of accessibility to a balanced diet at the level of scientifically substantiated norms of the population of Ukraine. The main problems of mankind are covered, such as: poverty, hunger, malnutrition and food security, etc. Based on statistics for the last few years, the article has calculated and reflected such indicators as: the level of poverty in Ukraine according to national accounts and the upper poverty level of $\$ 5.50$. US per day according to the World Bank, \%, the dynamics of indicators of meat consumption in Ukraine, the compliance of indicators of meat consumption in Ukraine with rational standards, etc. The importance of solving problematic issues of food security, which affects the level of socio-economic development of society and countries in general, the ratio of production, consumption and demand for sugar and oil in Ukraine, the prevalence of malnutrition in children and adults in Ukraine, the ratio of nutrition standards in secondary schools for one-time nutrition of students and the physiological needs of the population of Ukraine in basic nutrients and energy. The concept of rational nutrition is revealed. The state of food security determines, in particular, the level of food security, is the key to socio-economic development of society. For the world agricultural system there is a growing trend in declining inventories, rising prices, increasing differences in the level of agricultural development in countries with economic crises and globalization. The availability of a balanced diet at the level of scientifically sound standards for all segments of the population is also considered, which today is one of the main challenges of our time, which gives our study importance and significance.

Key words: production, consumption, indicators, caloric content of food, norm of consumption, production, innovative technologies.

\section{Доступність збалансованого харчування на рівні науково обгрунтовних норм для всіх верств населення України}

\author{
А. С. Ягодзінська
}

Миколаївський національний аграрний університет, м. Миколаїв, Украӥна 
Раціональне харчування (гаtіо - розумний) - це фізіологічно повноцінне харчування здорових людей із врахуванням їх віку, статі, характеру прачі та інших факторів. Раціональне харчування сприяє збереженню здоров'я, опірності шкідливм факторам навколишнього середовища, високій фізичній та розумовій працездатності, а також активному довголіттю. Статтю присвячено питанням доступності збалансованому харчуваню на рівні науково обтрунтованих норм населення Украӥни. Висвітлено основні проблеми людства таких як: бідність, голод, недостатнє харчування та продовольче забезпечення, та ін. На основі статистичних даних за останні декілька років у статті було розраховано та відображено такі показники як: рівень бідності в Україні за національними рахунками та верхній рівень бідності в 5,50 дол. США на день за даними Світового банку, \%, динаміку індикаторів споживання м'яса в Украӥні, відповідність індикаторів спожсвання м'яса в Україні раціональним нормам та ін. Вказується на важливість вирімення проблемних питань продовольчого забезпечення, щяо впливає на рівень сочіально-економічного розвитку суспільства країн і регіонів світу загалом, співвідношення виробництва, споживання та потреби иукру та олї в Украӥні, поширеність захворювань в результаті неправильного харчування у дітей та дорослих в Україні, співвідношення норм харчування у загальноосвітніх навчальних закладах для одноразового харчування учнів та фізіологічних потреб населення Украӥни в основних харчових речовинах і енергї. Розкрито поняття рачіонального харчування. Стан продовольчої безпеки визначає, зокрема, рівень забезпеченості населення продовольством, є запорукою сочіально-економічного розвитку суспільства. Для світової аграрної системи зростає тендениія у зменшенні товарних запасів, зростання иін, посилення відмінностей у рівні розвитку сільського господарства краӥн в умовах економічних криз та світової глобалізаџіі. Також розглянуто доступність збалансованого харчування на рівні науково обгрунтованих норм для всіх верств населення, щзо на сьогоднішній день є одним із головних викликів сучасності, щзо надає нашому дослідженню важливість та значимість.

Ключові слова: виробництво, споживання, індикатори, калорійність харчування, норма споживання, продукція, інноваційні технології.

\section{Вступ}

У різні історичні часи склад їжі й характер харчування змінювались залежно від розвитку виробничих сил суспільства, природно-кліматичних умов, напрямку господарської діяльності тощо. Характер харчування населення формувався поступово залежно від економічного і культурного рівня розвитку країни 3 урахуванням національних звичаїв і особливостей. Продукти харчування є рослинного і тваринного походження. Найбільш розповсюджені продукти рослинного походження: злакові й продукти їх переробки, овочі, фрукти, ягоди, гриби. До продуктів тваринного походження відносять м'ясо, рибу, яйця, молоко і молочні продукти. Харчовий раціон людини складається із харчових продуктів, які містять білки, жири, вуглеводи, вітаміни, мінеральні солі і в достатній кількості воду. Поєднання харчових продуктів у раціоні повинно бути науково обгрунтованим для всіх верств населення України в такій кількості, щоб воно забезпечувало всі фізіологічні потреби організму. Харчування є основною біологічною потребою людини. Неправильне харчування впливає на розвиток організму, знижує його захисні сили, може бути причиною багатьох хвороб. В. І. Смоляр вважає, що більше ніж половина випадків передчасної смерті (до 65 років) чоловіків і жінок в Україні зумовлена хворобами, у виникненні яких харчування відіграє важливу роль, що надає нашому дослідженню особливу важливість, значимість та актуальність.

\section{Матеріал та методи дослідження}

У процесі дослідження було застосовано наукові методи дослідження такі як: математичний, логічний, розрахунково-конструктивний та статистичний. Аналіз останніх досліджень та публікацій провідних вчених формує загальний висновок, що основна частина людства недоїдає. У процесі проведеного нами аналізу на основі наукових праць провідних фахівців та науковців, економічних та політичних експертів формується висновок що базисом основних проблем у сфері продовольчого забезпечення є низький рівень кваліфікації фахівців у сфері продовольчого забезпечення, відсутність науково обгрунтованого підходу щодо ефективного використання природних ресурсів та неудосконаленість законодавства які негативно відображаються на економічних та екологічних показниках.

Саме на основі збалансованості харчування та забезпеченні продовольчої безпеки нині будується сучасна державна політика переважної більшості країн світу. Продовольча безпека ефективно реалізується тоді, коли населення забезпечене в кількісному відношенні безпечної, і якісної їжі, щоб задовольнити свої для ведення активного і здорового способу житТя.

\section{Результати та їх обговорення}

Для подолання складних викликів, 3 якими стикається світ, потрібні трансформаційні дії, прийняття принципів сталості та подолання першопричин бідності та голоду. Продовольство та сільське господарство можуть допомогти досягти “Цілі сталого розвитку" (ЦСР), які ще називають “Глобальними цілями" - це загальний заклик до дій, спрямованих на те, щоб покінчити з бідністю, захистити планету i забезпечити мир і процвітання для всі людей у світі. Правильно харчуючись, діти можуть вчитися, люди вести здорове і продуктивне життя, а суспільства процвітати; сільське господарство, що охоплює рослинництво, тваринництво, рибне господарство та ліси, $\epsilon$ найбільшим роботодавцем у світі, найвагомішим економічним сектором для багатьох країн i, при цьому, забезпечує основне джерело продовольства та доходів для бідних (FAO, 2018).

Подолання бідності у всіх iii формах та усюди. Згідно національної методології Світового банку для України коефіцієнт бідності в Україні у 2018 році становив 1,3\%. Показники помірного та верхнього рівнів бідності в Україні за методикою Світового банку знижуються, причому коефіцієнт верхнього рівня бідності (питома вага людей, які живуть на суму 3,21-5,50 дол. США в день) 32002 по 2016 роки 
зменшився в сім разів. Проте, Світовий банк не дає дані у розрізі сільського та міського населення.

Відповідно до Національної доповіді 2017 “Цілі сталого розвитку: Україна” до системи індикаторів, що визначають перше завдання ЦСР2 "Подолання голоду, розвиток сільського господарства”, віднесено три індикатори (Goychuk, 2017):

1. Споживання м'яса в розрахунку на одну особу, кг/рік;
2. Споживання молока в розрахунку на одну особу, кг/рік;

3. Споживання фруктів в розрахунку на одну особу, кг/рік.

За розрахованими даними динаміка індикаторів споживання м'яса в Україні характеризується стійкими показниками зростання до 2013 року (табл. 1).

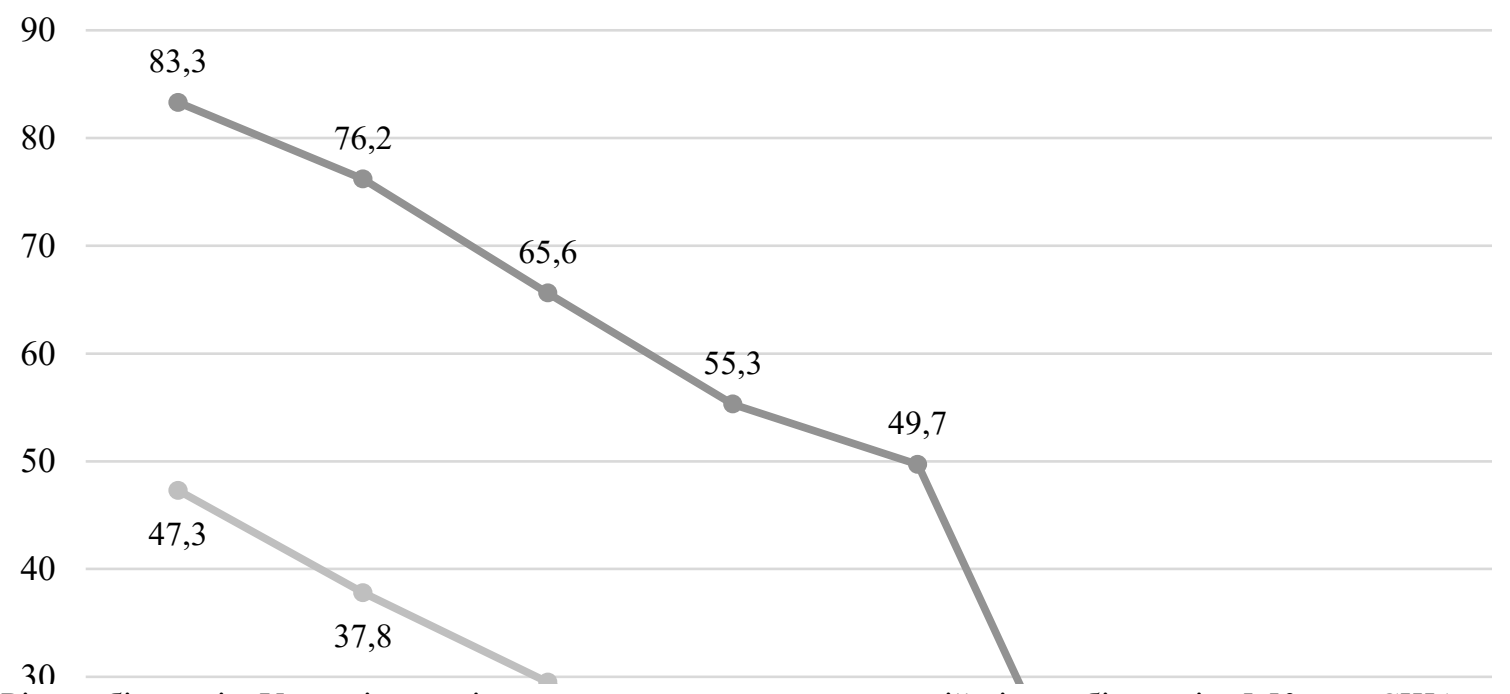

Рис. 1. Рівень бідності в Україні за національними рахунками та верхній рівень бідності в 5,50 дол. США на день за даними Світового банку, \%

Джерело: побудовано автором за даними Світового банку (World Bank, 2019)

Таблиця 1

Динаміка індикаторів споживання м’яса в Україні

\begin{tabular}{|c|c|c|c|c|c|c|c|c|}
\hline Показники & 2000 p. & 2005 p. & $2010 \mathrm{p}$. & 2013 p. & 2014 p. & $2015 \mathrm{p}$. & 2016 p. & $2017 \mathrm{p}$. \\
\hline $\begin{array}{l}\text { Споживання, кг на рік } \\
\text { Динаміка споживання по відношенню } \\
\text { до } 2000 \text { року: }\end{array}$ & 32,8 & 39,1 & 52,0 & 56,1 & 54,1 & 50,9 & 51,4 & 51,7 \\
\hline $\begin{array}{ll}\text { - } & \text { кг на рік } \\
\text { - } & \%\end{array}$ & $\begin{array}{c}\mathrm{x} \\
100,0\end{array}$ & $\begin{array}{c}6,3 \\
119,2\end{array}$ & $\begin{array}{c}19,2 \\
158,5\end{array}$ & $\begin{array}{c}23,3 \\
171,0\end{array}$ & $\begin{array}{c}21,3 \\
164,9\end{array}$ & $\begin{array}{c}18,1 \\
155,2\end{array}$ & $\begin{array}{c}18,6 \\
156,7\end{array}$ & $\begin{array}{c}18,9 \\
157,6\end{array}$ \\
\hline $\begin{array}{l}\text { Динаміка споживання по відношенню } \\
\text { до попереднього року }\end{array}$ & & & & & & & & \\
\hline $\begin{array}{ll}- & \text { кг на рік } \\
\text { - } & \% \\
\end{array}$ & $\begin{array}{l}\mathrm{X} \\
\mathrm{X}\end{array}$ & $\begin{array}{l}\mathrm{X} \\
\mathrm{X}\end{array}$ & $\begin{array}{l}\mathrm{x} \\
\mathrm{x}\end{array}$ & $\begin{array}{l}\mathrm{x} \\
\mathrm{x}\end{array}$ & $\begin{array}{l}-2,0 \\
96,4\end{array}$ & $\begin{array}{l}-3,2 \\
94,1 \\
\end{array}$ & $\begin{array}{c}0,5 \\
101,0 \\
\end{array}$ & $\begin{array}{c}0,3 \\
100,6\end{array}$ \\
\hline
\end{tabular}

Джерело: розраховано за даними Державної служби статистики України (Ukraine in numbers, 2017)

Однак після 2013 року індикатор споживання м'яса зменшується або залишається практично незмінним. Така ситуація тим більш неприйнятна, зважаючи на той факт, що споживання м'яса в Україні не відповідає раціональним нормам: за досліджуваний період співвідношення фактичних норм споживання до раціональних не перевищувало $70 \%$; найгірші показники встановлено у 2000 та 2005 роках - відповідно 41 та $49 \%$ (табл. 2).

Таким чином дефіцит споживання м'яса в Україні відносно раціональної норми споживання (80 кг на рік) за період з 2000 по 2017 роки становив від 28 до 47 кг на рік (рис. 2).
Більшість науковців підтримують тезу про те, що дефіцит споживання пов'язаний 3 низькою купівельною спроможністю населення, з чим важко не погодитись. Але ми вважаємо, що висока ціна на продукцію $\epsilon$ не першопричиною, а похідною - це результат недостатньої пропозиції продукції. Таку гіпотезу підтверджує той факт, що співвідношення між рівнем споживання та обсягами виробництва продукції майже стовідсоткове, а в 2005, 2010 та 2013 роках навіть його перевищує - населення не може споживати більше, навіть за значного зменшення ціни, бо продукції виробляється недостатньо якісно. 


\section{Таблищя 2}

Відповідність індикаторів споживання м'яса в Україні раціональним нормам

\begin{tabular}{|c|c|c|c|c|c|c|c|c|}
\hline Показники & $2000 \mathrm{p}$. & $2005 \mathrm{p}$. & $2010 \mathrm{p}$. & $2013 \mathrm{p}$. & $2014 \mathrm{p}$. & $2015 \mathrm{p}$. & $2016 \mathrm{p}$. & $2017 \mathrm{p}$. \\
\hline $\begin{array}{l}\text { Співвідношення фактичного спо- } \\
\text { живання до раціональної норми, \% } \\
\text { Співвідношення фактичного спо- } \\
\text { живання до раціональної норми, } \\
\text { в.П.: }\end{array}$ & 41,0 & 48,9 & 65,0 & 70,1 & 67,6 & 63,6 & 64,3 & 64,6 \\
\hline $\begin{array}{ll}\text { - } & \text { по відношенню до } 2000 \\
\text { - } & \text { року } \\
\text { по відношенню до попе- }\end{array}$ & $\mathrm{x}$ & 7,9 & 24,0 & 29,1 & 26,6 & 22,6 & 23,3 & 23,6 \\
\hline
\end{tabular}

Джерело: розраховано за даними Державної служби статистики України (Ukraine in numbers, 2017)

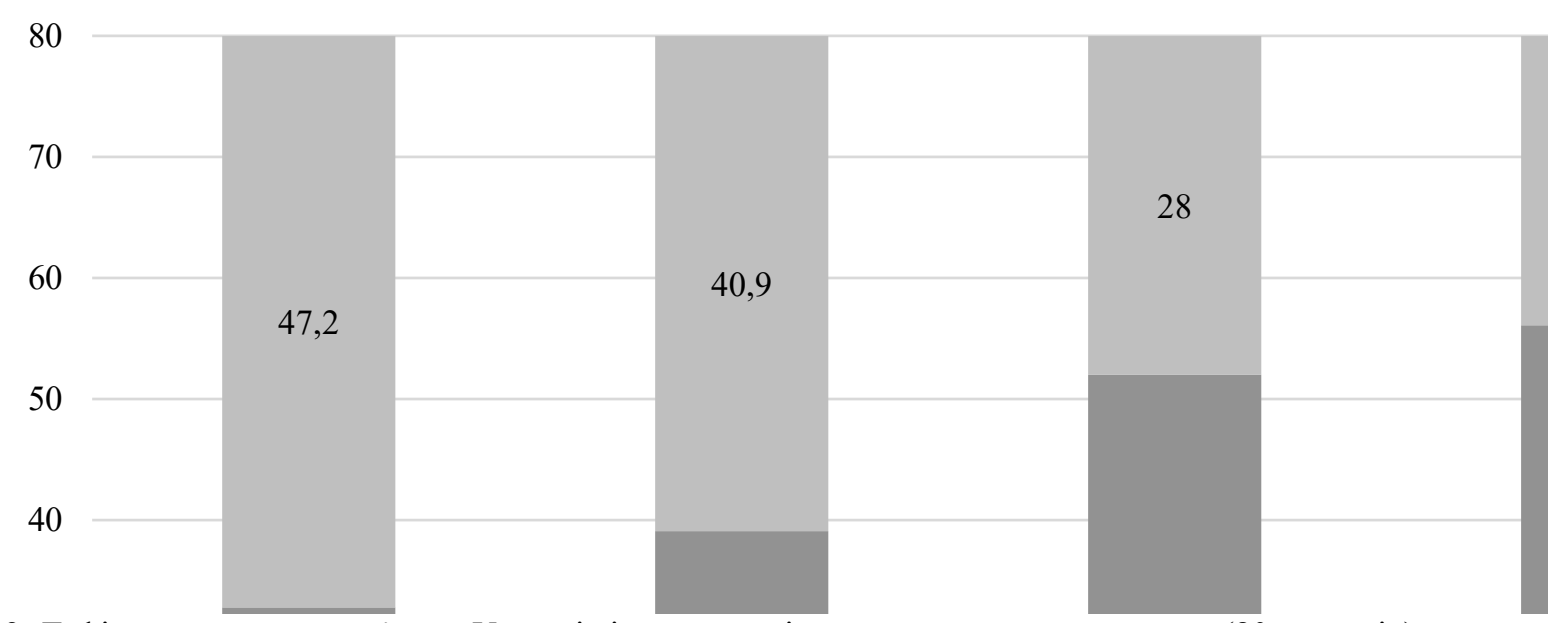

Рис. 2. Дефіцит споживання м'яса в Україні відносно раціональної норми споживання (80 кг на рік) Джерело: розраховано за даними Державної служби статистики України (Ukraine in numbers, 2017)

Зважаючи на попередній висновок, логічно припустити, що у розрізі областей України є значні коливання обсягів споживання основних видів продовольства, адже обсяги виробництва продукції по регіонах значно відрізняються.

Дійсно, лише у 7 областях - Вінницькій, Дніпропетровській, Донецькій, Запорізькій, Київській, Кіровоградській, Харківській - рівень споживання м'яса вищий або на рівні даних по Україні; різниця між найвищим рівнем (Київська область - 66,2 кг) та найменшим рівнем (Луганська та Івано-Франківська області - 42,0 та 42,9 кг) споживання м'яса становить 23,3-24,2 кг або 35,2-36,5 \%; першу трійку областей у рейтингу дефіциту споживання м'яса (від найменшого до найбільшого) складають Київська, Дніпропетровська та Донецька області, а останню - Луганська, Івано-Франківська та Чернівецька області (Statistical Yearbook of Ukraine, 2017).

В жодній області фактичний рівень споживання відносно раціональної норми не забезпечує 100 відсотків, а в 21 області - Вінницькій, Волинській, Житомирській, Закарпатській, Запорізькій, ІваноФранківській, Кіровоградській, Луганській, Львівській, Миколаївській, Одеській, Полтавській, Рівненській, Сумській, Тернопільській, Харківській, Херсонській, Хмельницькій, Черкаській, Чернівецькій, Чернігівській - він не перевищує 70-и відсотковий бар'єр, що становить 25 і більше кг дефіциту споживання м'яса. В більшості цих областей обсяг виробництва м'яса на одну особу менший за рівень фактичного споживання, що підтверджує раніше висунуту гіпотезу про значний вплив на обсяги споживання м'яса обсягів виробництва продукції та суттєві коливання, у зв'язку з цим, рівня споживання продукції у різних областях країни (Gross output of agriculture of Ukraine, 2015).

\section{Висновки}

Проведені дослідження на основі показників за останні декілька років доводять, що в Україні спостерігаються значні коливання індексів продукції сільського господарства та відмінності у темпах їх росту у розрізі галузей сільського господарства. Значно меншими $\epsilon$ ці коливання у розрізі категорій господарств та регіонів. Тобто, на кінцеві індикатори значний суттєвий вплив матимуть будь-які зрушення у структурі виробництва продукції за галузями, та відображатимуться на збалансованому харчуванні всіх верств населення України.

Таким чином наше наукове дослідження стосовно доступності збалансованого харчуванні на рівні науково обгрунтованих норм для всіх верств населення України, потребує досягнення бажаних показників у заплановані строки вимагає прискорення зміни визначальних факторів збільшення споживання - обсягів 
виробництва продукції через підвищення продуктивності сільського господарства, насамперед за рахунок використання інноваційних технологій та забезпечення створення стійких систем виробництва продуктів харчування, що сприяють збереженню екосистем i поступово покращують якість земель та грунтів, насамперед за рахунок використання інноваційних технологій.

\section{References}

FAO (2018). Transforming food and agriculture to achieve the sdgs 20 interconnected actions to guide decision-makers. Food and agriculture organization of the united nations. Rome. URL: http://www.fao.org/3/I9900EN/i9900en.pdf.

World Bank (2019). Poverty headcount ratio at $\$ 5.50$ a day (2011 PPP) (\% of population) World, Ukraine. URL: https://data.worldbank.org/indicator/SI.POV.UMIC?en $\mathrm{d}=2018$ \&locations $=1 \mathrm{~W}$ -

UA\&most_recent year_desc $=$ false\&start $=2002 \&$ view $=$ chart.

Goychuk, O. I. (2017). Basic principles of food security in a global food crisis. Access mode: http://elibrary.nubip.edu.ua/13648/1/12goi.pdf （in Ukrainian).

Ukraine in numbers (2017). [Electronic resource]. State Statistics Service of Ukraine. Mode of access to the resource: http://www.ukrstat.gov.ua (in Ukrainian).

Statistical Yearbook of Ukraine (2017). [Electronic resource] State Statistics Service of Ukraine. Mode of access to the resource: http://www.ukrstat.gov.ua (in Ukrainian).

Gross output of agriculture of Ukraine (2015). [Electronic resource] State Statistics Service of Ukraine. Mode of access to the resource: http://www.ukrstat.gov.ua (in Ukrainian). 